\title{
PENERAPAN DISCOVERY LEARNING MELALUI AKTIVITAS TSTS DAN WINDOW SHOPPING PADA SISWA KELAS IX
}

\author{
Heri Suhud Kustoyo \\ SMP Negeri 1 Cilacap \\ Email: kustoyo2904@gmail.com
}

\begin{abstract}
ABSTRAK
Penelitian ini bertujuan untuk meningkatkan hasil belajar dan minat peserta didik kelas IX J SMP Negeri 1 Cilacap Tahun Pelajaran 2019/2020. Metode penelitian yaitu deskripsi komparatif dengan membandingkan antara nilai awal dengan nilai hasil perlakuan baru. Pengumpulan data pada penelitian ini menggunakan instrumen tes berupa soal yang digunakan untuk mengetahui hasil belajar. Proses kegiiatan pembelajaran dilakukan dengan 6 tahapan yaitu : 1) Stimulation dengan menayangkan video sistem reproduksi; 2) Problem statement dengan menggali pertayaan dari video; 3) Data Collection membagi peserta didik menjadi 8 kelompok mencari informasi sistem reproduksi manusia; 4) Data processing dengan memberi tugas membuat mading tentang sistem reproduksi 5) verifiacation dengan berbagi tugas 2 orang berperan menjaga stand dan menjelaskan isi mading; 2 orang lainnya berperan menjadi tamu yang melakukan kegiatan kunjungan ke stand untuk diskusi. 6) Generalization ,guru memandu jalannya presentasi dan menarik kesimpulan. Perubahan perilaku setelah mengikuti pembelajaran Sistem Reproduksi Manusia menggunakan model Discovery learning melalui aktivitas Two Stay Two Stray (TSTS) dan window Shopping yaitu meningkatkan keterampilan abad 21 yaitu keterampilan 4K (berfikir Kritis, Kreatif, Kerjasama dan Komunikasi) dan meningkatkan literasi berupa literasi bahasa, literasi digital dan literasi sains. Hasil belajar peserta didik kelas IX J SMP Negeri 1 Cilacap Tahun Pelajaran 2019/2020 setelah mengikuti pembelajaran Sistem Reproduksi Manusia model Discovery learning melalui aktivitas Two Stay Two Stray (TSTS) dan window Shopping diperoleh rata-rata nilai pengetahuan sebesar 84 lebih tinggi dibandingkan KKM IPA kelas IX yang ditetapkan SMP N 1 Cilacap. Daya serap peserta didik mencapai $100 \%$ dan ketuntasan belajar mencapai $93.8 \%$.
\end{abstract}

Kata Kunci : Discovery learning, Two Stay Two Stray (TSTS), window Shopping, keterampilan abad 21 


\section{PENDAHULUAN}

IPA adalah salah satu rumpun ilmu yang digunakan untuk mengukur kemajuan pendidikan suatu negara. Sesuai dengan kurikulum 2013, IPA dirancang untuk memperkuat kompetensi peserta didik dari segi pengetahuan, keterampilan dan sikap secara utuh. Penguatan kompetensi peserta didik tersebut diharapkan peserta didik Indonesia mampu bersaing diajang perlombaan di tingkat Internasional seperti PISA ( Program For Internasional Student Assessment).. Dari hasil nilai tes PISA tahun 2018, Indonesia menduduki peringkat 75 dari 80 negara atau urutan 6 dari bawah untuk nilai membaca, matematika dan sains yang diujikan.

Tolak ukur mutu pendidikan selain hasil PISA juga dilihat dari hasil UN. Hasil ujian nasional (UN) di Indonesia juga dapat menjadi data landasan perbaikan mutu pendidikan. Informasi tentang hasil UN secara detail tentang setiap capaian butir soal dapat digunakan sebagai refleksi atau umpan balik bagi pembelajaran di setiap satuan pendidikan. Info dari hasilun Puspendik kemendikbud menunjukkan ratarata UN IPA sebesar 48 masih dibawah 55 threshold yang ditentukan oleh puspendik (Kemendikbud Tahun 2019). Rata -rata UN IPA yang rendah disebabkan materi IPA yang terlalu luas dan teksbook hal ini menyebabkan siswa kesulitan menghapal materi. Contohnya materi Sistem Reproduksi Manusia, siswa diminta mempelajari 17 inidikator pengetahuan dari konsep pembelahan sel sampai dengan upaya pencegahan penyakit reproduksi. Bagi sebagian siswa hal ini cukup menyulitkan siswa untuk memahami dan menghapal bagian-bagian dari sistem reproduksi manusia.

Pada penelitian Aniatus Sa'diyah pada tahun 2016 tentang gaya hidup masyarakat Surabaya dalam memanfaatkan perpustakaan cafe, sebesar 54,7\% masyarakat Surabaya memanfaatkan perpustakaan café karena memberi rasa nyaman dalam belajar. Hal ini memberi insipirasi bagi saya sebagai pendidik untuk membuat suasana belajar seperti cafe dimana tersedia beberapa menu berupa mading pembelajaran, peserta didik berbagi tugas, 2 orang berjaga stand dan 2 peserta didik lainnya mmelakukan akitivitas window Shoopping yaitu jalan-jalan distand mading lainnya untuk mencari informasi tentang mading 
pembelajaran tersebut.

Berdasarkan permasalahan di atas, salah satu strategi pembelajaran yang efektif untuk meningkatkan mutu pendidikan sesuai abad 21 berupa kemampuan keterampilan 4K (Kritis, Kreatif, Kerjasama dan Komunikasi) dan kemampuan literasi dengan cara menyenangkan seperti kegiatan di perpustakaan cafe adalah dengan menggunakan model pembelajaran Discovery Learning melalui aktivitas TSTS (Two stay Two Stray) dan window Shopping untuk meningkatkan hasil belajar peserta didik kelas IX J dalam pembelajaran sistem reproduksi manusia.

Berdasarkan latar belakang di atas, masalah yang dapat dirumuskan adalah "Bagaimana penggunaan model Discovery Learning melalui aktivitas Two Stay Two Stray (TSTS) dan window Shopping dalam pembelajaran Sistem Reproduksi Manusia untuk meningkatkan hasil belajar dan minat peserta didik kelas IX J SMP Negeri 1 Cilacap Tahun Pelajaran 2019/2020" adapun tujuan penulisan laporan ini adalah Mendeskripsikan hasil belajar peserta didik kelas IX J SMP Negeri 1 Cilacap Tahun Pelajaran 2019/2020 setelah mengikuti pembelajaran Sistem Reproduksi Manusia menggunakan model model Discovery learning melalui aktivitas Two Stay Two Stray (TSTS) dan window Shopping

\section{METODE}

Pada penelitian ini, penulis mengggunakan model pembelajaran Discovery learning dipandu dengan aktivitas TSTS dan windows shooping. Model Menurut Bruner (Lefancois dalam Emetembun, 1986:103) "Model Discovery Learning didefinisikan sebagai proses pembelajaran yang terjadi bila pelajar tidak disajikan dalm bentuk finalnya, tetapi diharapkan mengorganisasi sendiri”. Menurut Budiningsih (2005:43), “Model Discovery Learning adalah cara belajar memahami konsep, arti, dan hubungan melalui proses intuitif untuk akhirnya sampai kepada suatu kesimpulan".

Penemuan adalah terjemahan dari discovery. Menurut Sund "discovery adalah proses mental dimana siswa mampu mengasimilasikan sesuatu konsep atau prinsip". Proses mental tersebut ialah mengamati, mencerna, 
mengerti, mengolong-golongkan, membuat dugaan, menjelaskan, mengukur, membuat kesimpulan dan sebagainya (Roestiyah, 2001:20), sedangkan menurut Bruner, "penemuan adalah suatu proses, suatu jalan/cara dalam mendekati permasalahan bukannya suatu produk atau item pengetahuan tertentu". Dengan demikian di dalam pandangan Bruner, belajar dengan penemuan adalah belajar untuk menemukan, dimana seorang siswa dihadapkan dengan suatu masalah atau situasi yang tampaknya ganjil sehingga siswa dapat mencari jalan pemecahan (Markaban, 2006:9).

Aktivitas Two Stay Two Stray adalah metode dua tinggal dua tamu. Menurut Agus Suprijono, pembelajaran dengan metode ini diawali dengan pembagian kelompok. Setelah kelompok terbentuk guru memberikan tugas berupa permasalahan-permasalahan yang harus mereka diskusikan jawabannya. Setelah diskusi intrakelompok usai, dua orang dari masing-masing kelompok meninggalkan kelompoknya untuk bertamu kepada kelompok yang lain. Anggota kelompok yang tidak mendapat tugas sebagai tamu mempunyai kewajiban menerima tamu dari suatu kelompok. Tugas mereka adalah menyajikan hasil kerja kelompoknya kepada tamu tersebut. Dua orang yang bertugas sebagai tamu diwajibkan bertamu kepada semua kelompok. Jika mereka telah usai menunaikan tugasnya, mereka kembali ke kelompoknya masing-masing. Setelah kembali ke kelompok asal, baik peserta didik yang bertugas bertamu maupun mereka yang bertugas menerima tamu mencocokkan dan membahas hasil kerja yang telah mereka tunaikan (Suprijono, 2009: 93)

Struktur Two Stay Two Stray yaitu memberi kelompok untuk membagikan hasil dan informasi dengan kelompok lain”. Adapun langkah-langkah pelaksanaan model pembelajaran kooperatif tipe Two Stay Two Stray seperti yang diungkapkan, antara lain (Lie dalam Yusritawati, 2009: 14): 1) Guru membagi peserta didik dalam beberapa kelompok yang setiap kelompoknya terdiri dari empat peserta didik. Kelompok yang dibentuk merupakan kelompok heterogen dengan tujuan untuk memberikan kesempatan pada peserta didik untuk saling membelajarkan (Peer Tutoring) dan saling mendukung. 2) Guru memberikan sub pokok bahasan pada tiap-tiap kelompok untuk dibahas bersama-sama dengan anggota kelompoknya masing-masing. 3) Peserta didik bekerjasama dalam kelompok beranggotakan empat orang. Hal ini bertujuan untuk memberikan kesempatan kepada peserta didik untuk dapat terlibat secara aktif dalam proses berpikir. 4) Setelah selesai, dua orang 
dari masing-masing kelompok meninggalkan kelompoknya untuk bertamu ke kelompok lain. Struktur Two Stay Two Stray yang dimaksud tampak seperti pada gambar berikut ini:

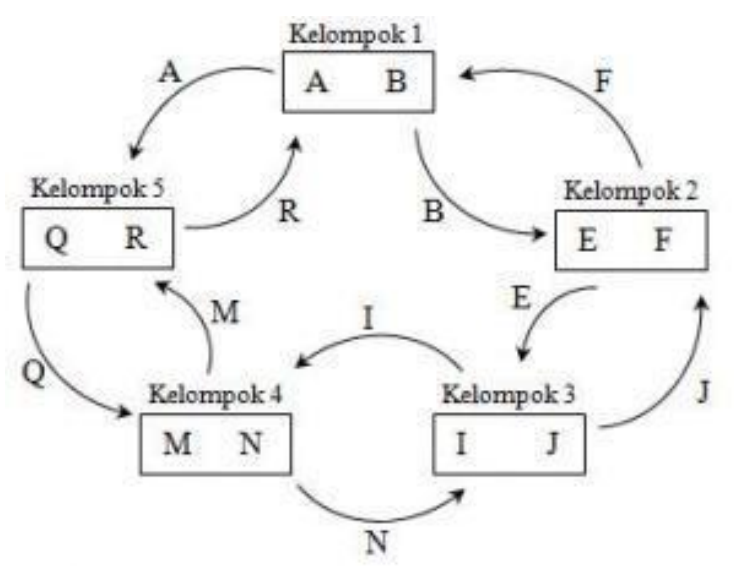

Gambar 1. Struktur Two Stay Two Stray (Lie dalam Yusritawati, 2009: 14)

1)Dua orang yang tinggal dalam kelompok bertugas membagikan hasil kerja dan informasi mereka ke tamu mereka. 2) Tamu mohon diri dan kembali ke kelompok mereka sendiri dan melaporkan temuan mereka dari kelompok lain. 3) Kelompok mencocokkan dan membahas hasil-hasil kerja mereka. 4) Masing-masing kelompok mempresentasikan hasil kerja mereka.

Menurut Rahma, W (2017. Window Shopping adalah model pembelajaran berbasis kerja kelompok dengan melakukan berbelanja keliling melihat-lihat hasil karya kelompok lain untuk menambah wawasannya Berdasar salah satu praktik pembelajaran terbaik dilakukan di SDN 2 Banjarnegara Jawa Tengah menggambarkan bahwa, "model pembelajaran kooperatif tipe window shopping (belanja hasil karya) akan mengantarkan peserta didik pada penanaman karakter kerjasama, keberanian, demokratis, rasa ingin tahu, interaksi antar teman, dan bertanggung jawab (USAID, 2015). Peserta didik dapat berbelanja secara aktif dan dinamis dengan memajang hasil karya secara kreatif. Dua orang dari masingmasing kelompok menjaga hasil karya mereka (menjaga stand/toko). Anggota kelompok lainnya mengunjungi stand untuk melihat hasil karya kelompok lainnya (berbelanja) dengan memberi komentar dan penilaian sehingga setiap peserta dalam kelompok dapat memicu kreativitasnya. Pembelajaran seperti ini 
dapat menimbulkan situasi yang menyenangkan, tetapi tetap efektif sesuai tujuan pembelajaran yang dicapai.

Pengumpulan data pada penelitian ini menggunakan instrument tes berupa soal yang digunakan untuk mengetahui hasil belajar. Untuk menganalisis data yang telah terkumpul digunakan analisis deskripsi komparatif dengan membandingkan antara nilai awal (kondisi awal) dengan nilai hasil perlakuan baru. Pembelajaran Sistem Reproduksi Manusia pada peserta didik kelas IX J SMP Negeri 1 Cilacap menggunakan model Discovery Learning dan Two Stay Two Stray (TSTS) melalui Aktivitas Window Shopping pada materi sistem reproduksi pada manusia, yaitu pada kompeetensi dasar menghubungkan sistem reproduksi pada manusia dan gangguan pada sistem reproduksi, serta penerapan pola hidup yang menunjang kesehatan reproduksi.

Adapun langkah-langkah pembelajaran Sistem Reproduksi Manusia menggunakan model Discovery Learning melalui Aktivitas Two Stay Two Stray (TSTS) dan Window Shopping sebagai berikut : 1) Stimulation (Pemberian rangsangan) Pada tahapan pemberian rangsangan peserta didik diminta mengamati vidio “Proses terjadinya Bayi sampai melahirkan”; 2) Problem statemen (Pernyataan Masalah)Pada tahapan pernyataan masalah, guru memfasilitasi peserta didik untuk menanyakan hal-hal yang belum dipahami berdasarkan hasil pengamatan kemudian peserta didik diminta berfikir kritis terhadap pemberian rangsangan tayangan video proses terjadinya bayi sampai dilahirkan. Pada tahapan berfikir kritis, guru memandu peserta didik sehingga muncul pertanyaan seperti :

1.1 Apa fungsi organ organ penyusun sistem reproduksi pada laki - laki dan perempuan?

1.2 Bagaimana proses terbentuknya sperma dan ovum?

1.3 Bagaimana proses fertilisasi dan apa yang terjadi jika tidak terjadi proses fertilisasi?

1.4 Bagaimana proses kehamilan?

1.5 Apa Penyakit sistem reproduksi dan bagaimana pencegahannya dan seterusnya? 
Pada tahapan pengumpulan data, aktivitas TSTS pada discovery learning sebagai berikut : 1) Kelas dibagi menjadi 8 kelompok berdasarkan tingkat kemampuan akademik dan jenis kelamin, setiap kelompok terdiri dari 4 peserta didik (peserta didik berjumlah 32 peserta didik) dan 2) Peserta didik yang mendapat tugas berdasarkan sub pokok bahasan dalam sistem reproduksi manusia, kelompok 1 mengumpulkan berbagai informasi tentang pembelahan sel, kelompok 2 mengumpulkan berbagai informasi tentang organ reproduksi pada laki-laki, kelompok 3 mengumpulkan berbagai informasi tentang organ reproduksi pada perempuan, Kelompok 4 mengumpulkan berbagai informasi tentang Proses Spermatogensis, kelompok 5 mengumpulkan berbagai informasi tentang Oogenesis, kelompok 6 mengumpulkan berbagai informasi tentang Proses Menstruasi, kelompok 7 mengumpulkan berbagai informasi tentang ferlisasi dan proses kelahiran, Kelompok 8 mengumpulkan berbagai informasi tentang Penyakit reproduksi dari buku paket maupun sumber lain seperti internet.

Pada tahapan pengolahan data, aktivitas TSTS pada pembelajaran discovery learning sebagai berikut : 1) Guru memberi lembar kerja peserta didik berisi tentang teknis TSTS dan bahan diskusi; 2) Peserta didik membuat majalah dinding sesuai pokok bahasannya; dan 3) Masing-masing kelompok berdiskusi dengan bimbingan guru menuangkan berbagai informasi yang didapat didalam majalah dinding.

Pada tahapan pembuktian model pembelajaran discovery learning dengan aktivitas TSTS dan window Shopping sebagai berikut : 1) Peserta didik masingmasing kelompok berbagi tugas, dua orang menjaga stand madingnya dan dua orang lainnya meninggalkan kelompoknya untuk mengunjungi stand mading kelompok lainnnya; 2) Dua orang bertugas menjaga stand mempresentasikan madingnya kepada tamu yang berkunjung ke standnya; 3) Setelah waktu kunjungan dinyatakan selesai, dua peserta didik yang berkunjung ke stand kembali ke kelompok asal dan mempresentasikan hasil kunjungannya ke temannya yang tinggal distandnya; 4) Masing-masing kelompok berdiskusi mengerjakan lembar kerja yang telah disediakan; dan 5) Salah satu kelompok mempresentasikan hasil kunjuangan berdasarkan panduan lembar kerja didepan kelas.

Pada tahapan akhir, guru memandu jalannya presentasi dan menarik kesimpulan materi sistem reproduksi manusia.

\section{HASIL DAN PEMBAHASAN}

Kegiatan belajar mengajar dengan menggunakan model Discovery Learning) melalui Aktivitas Two Stay Two Stray (TSTS dan Window Shopping pada materi sistem reproduksi pada manusia, penulis sebagai guru melakukan pembukaan dengan salam pembuka dan berdoa untuk memulai pembelajaran kemudian mengecek kehadiran dan kondisi peserta didik serta mengecek kondisi ruangan, jika terdapat sampah atau kurang bersih dan rapi supaya dibersihkan. 
Setelah itu mengingatkan kembali materi sebelumnya tentang pembelahan sel.. Pada awal kegiatan ini, guru menayangkan video tentang proses kelahiran bayi. Dari tayangan tersebut guru menggali pertanyaan tentang video tersebut sehingga peserta didik berfikir kritis.

Pada tahap data collection, penulis sebagai guru membagi peserta didik menjadi 8 kelompok dimana tiap kelompok berisi 4 peserta didik. Peserta didik yang mendapat tugas berdasarkan sub pokok bahasan dalam sstem reproduksi manusia, kelompok 1 mengumpulkan berbagai informasi tentang pembelahan sel, kelompok 2 mengumpulkan berbagai informasi tentang organ reproduksi pada laki-laki, kelompok 3 mengumpulkan berbagai informasi tentang organ reproduksi pada perempuan, Kelompok 4 mengumpulkan berbagai informasi tentang Proses Spermatogensis, kelompok 5 mengumpulkan berbagai informasi tentang Oogenesis, kelompok 6 mengumpulkan berbagai informasi tentang Proses Menstruasi, kelompok 7 mengumpulkan berbagai informasi tentang ferlisasi dan proses kelahiran, Kelompok 8 mengumpulkan berbagai informasi tentang Penyakit reproduksi dari buku paket maupun sumber lain seperti internet. Proses pembuatan mading sistem reproduksi manusia dengan bimbingan guru sebagai Kegiatan Data processing (Pengolahan Data)

Kegiatan verification (Pembuktian ) melalui aktivitas TSTS dan window Shopping ditunjukkan gambar 2 ,gambar 3 dan gambar 4

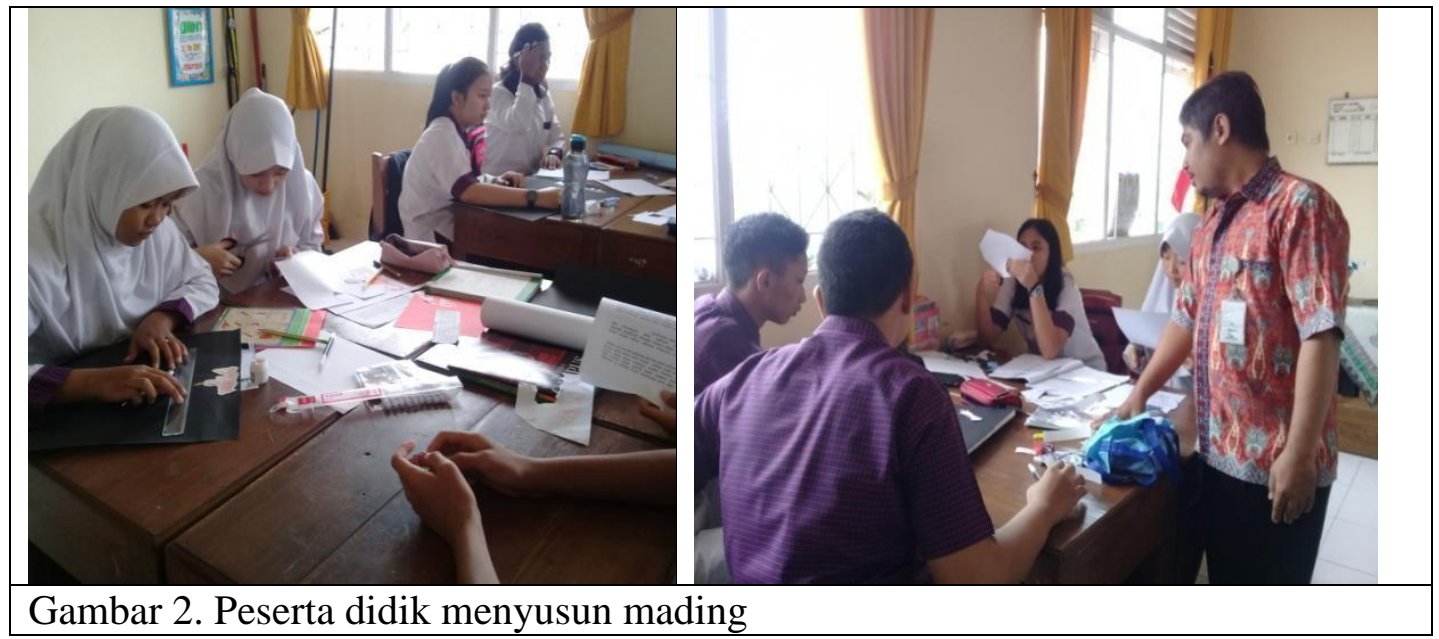


Setelah penyusunan mading, peserta didik melakukan aktivitas TSTS dan window Shopping dan berbagi tugas 2 orang berperan menjaga stand dan menjelaskan isi mading ketika ada tamu berkunjung dan 2 orang lainya berperan menjadi tamu yang melakukan kegiatan kunjungan ke stand lainya. Peserta didik yang bertugas sebagai tamu mencatat semua kegiatan kunjungan stand dan berbagi informasi ke teman yang bertugas sebagai penjaga stand. Kegiatan aktivitas window Shopping ditunjukkan gambar 3.

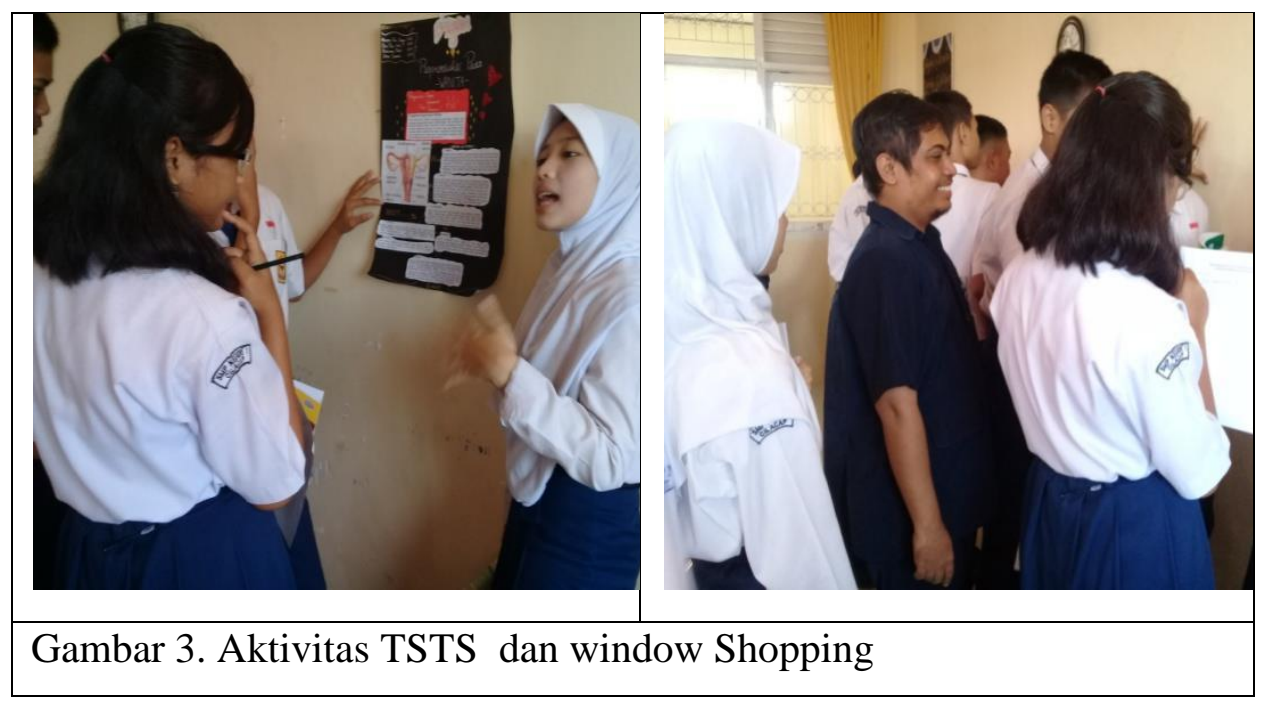

Kemudian peserta didik kembali ke kelompok masing masing dan berdiskusi mengerjakan LKPD yang diberikan guru. tersebut ditunjukkan gambar 5.

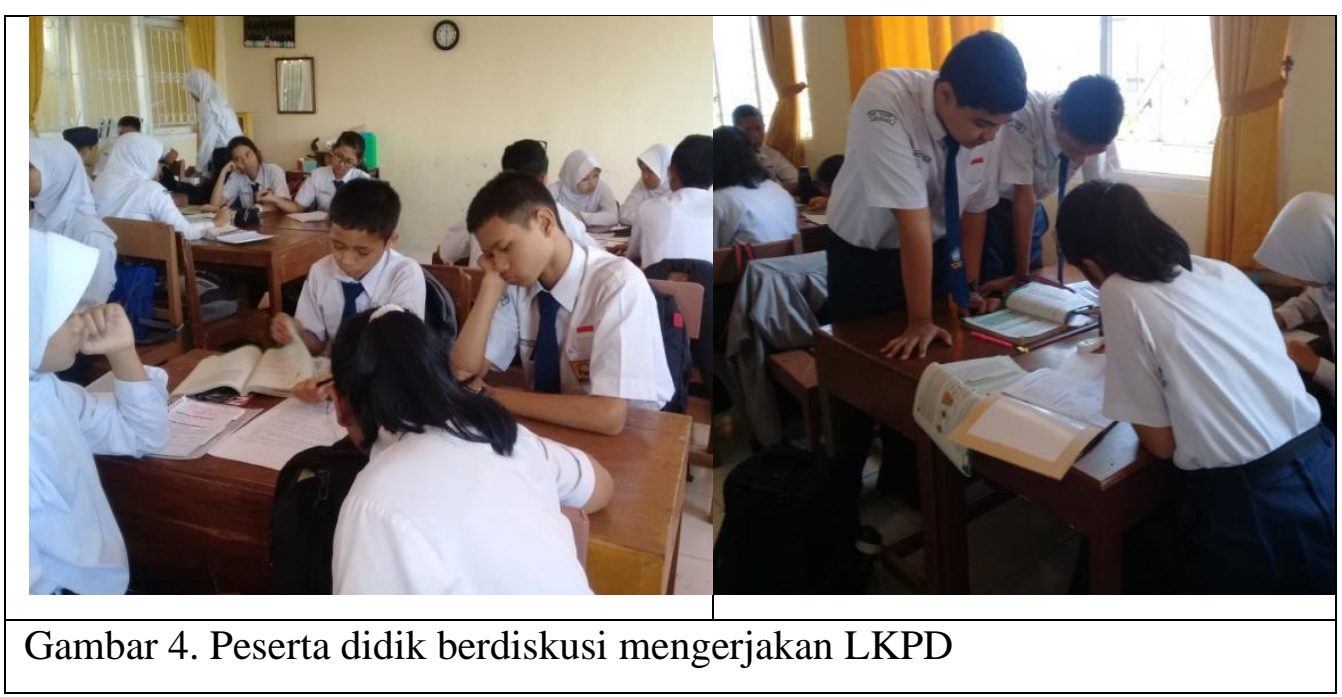




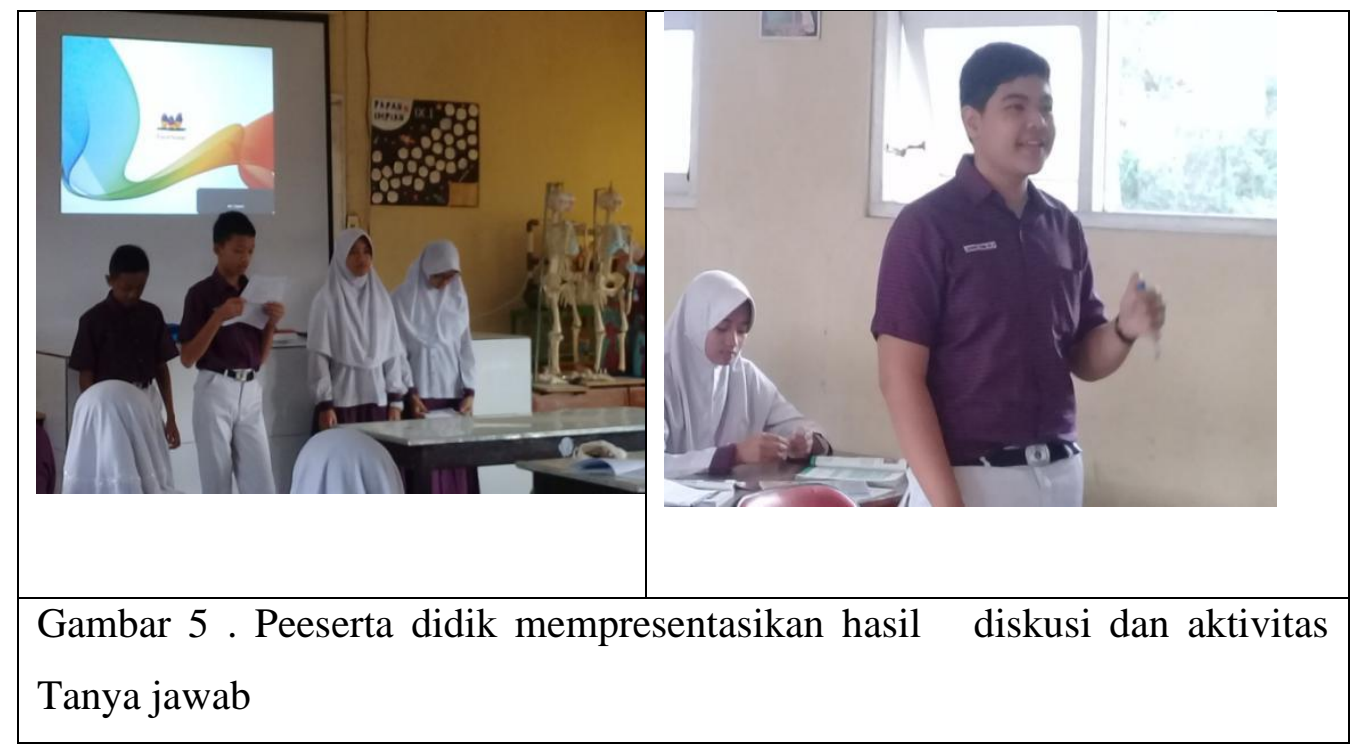

Tahapan berikutnya dari kegiatan verification (Pembuktian) adalah presentasi. Peserta didik mempresntasikan hasil kunjungan stand dan diskusi kelompok yang dipandu LKPD. Kegiatan Presentasi pada tahapan verification (Pembuktian) ditunjukkan gambar 5 Tahap berikutnya Generalization yaitu: guru memandu jalannya presentasi dan menarik kesimpulan materi sistem reproduksi manusia.. Diakhir kegiatan, peserta didik mengerjakan evaluasi untuk mengetahui pengaruh pembelajaran discovery learning melalui aktivitas TSTS dan window Shopping berpengaruh terhadap hasil belajar peserta didik

Penerapan pembelajaran Sistem Reproduksi Manusia dengan model Discovery Learning melalui Aktivitas Two Stay Two Stray (TSTS) dan Window Shopping telah meningkatkan keterampilan abad 21 meliputi keterampilan $4 \mathrm{~K}$ antara lain berfikir Kritis, Kreatif, Kerjasama dan Komunikasi serta meningkatkan literasi bahasa, literasi digital,literasi sains peserta didik 


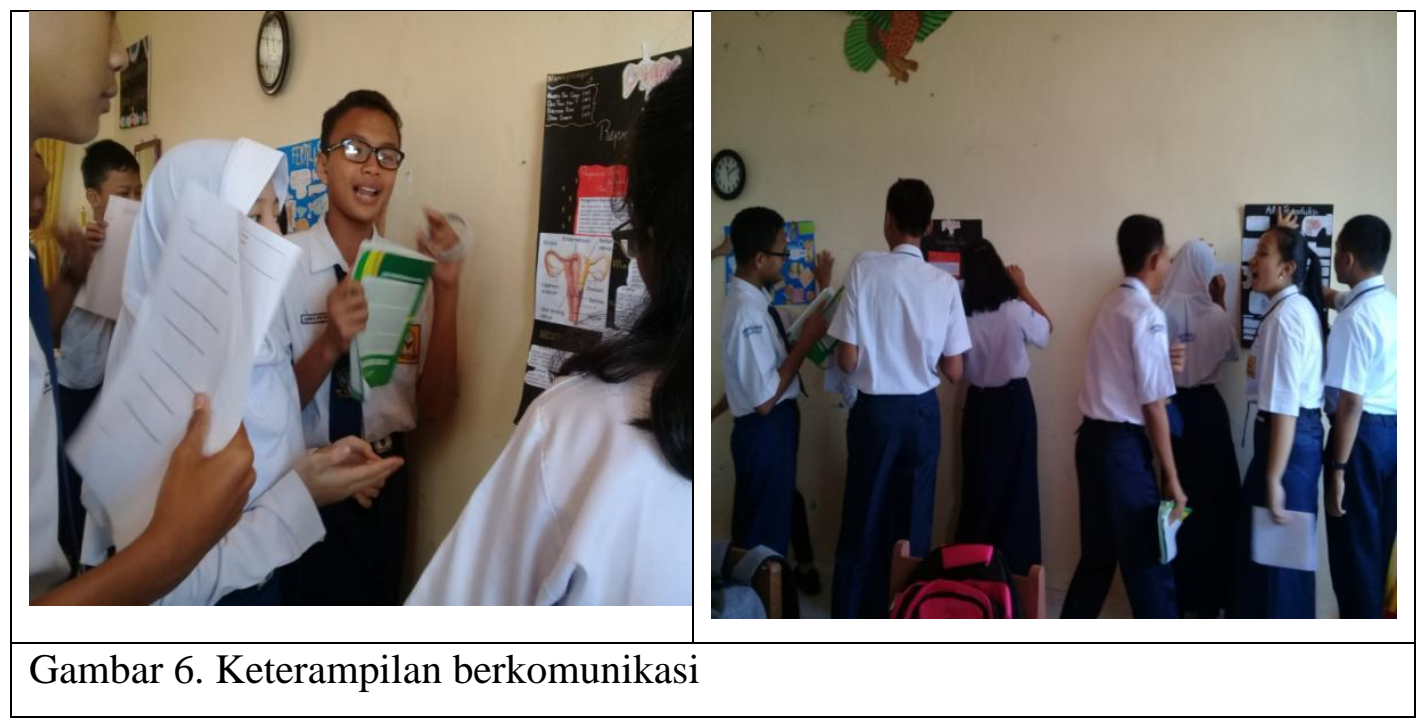

Pada Gambar 6 menunjukkan kegiatan TSTS melalui aktivitas window Shopping, peserta didik dilatih keterampilan berkomunikasi baik sebagai penyaji maupun sebagai tamu. Pada kegiatan tersebut peserta didik yang bertugas sebagai tamu dilatih untuk berfikir kritis (critical thingking) sedangkan penyaji menjawab pertanyaan-pertanyaan dari tamu. Kegiatan menjawab pertanyaan dari tamu melatih keterampilan problem solving.

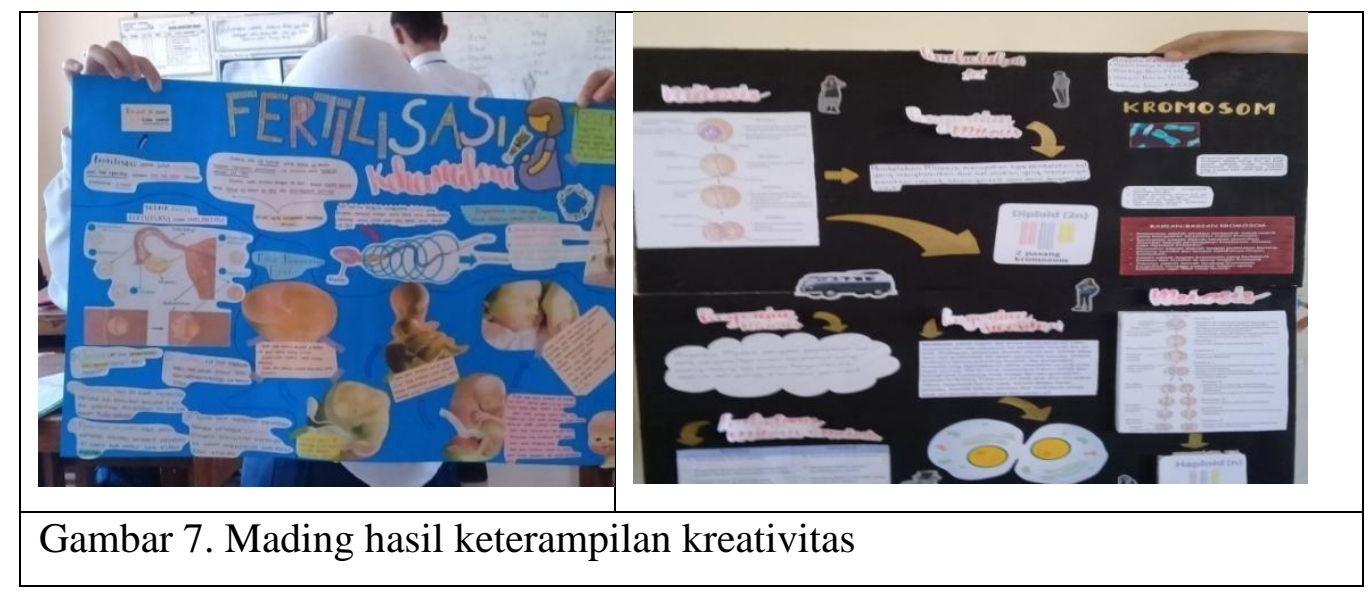

Gambar 7 menunjukkan kreatviitas peserta didik dalam menyajikan mading. Peserta didik mecari sumber referensi mading dari buku maupun ebook di internet kemudian dengan kreativitas peserta didik, bahan mading tersebut diringkas dan dipasang dengan bentuk bentuk yang menarik. Kegiatan tersebut 
melatih kreatifitas yang merupakan keahlian abad 21 yang harus dimiliki peserta didik.

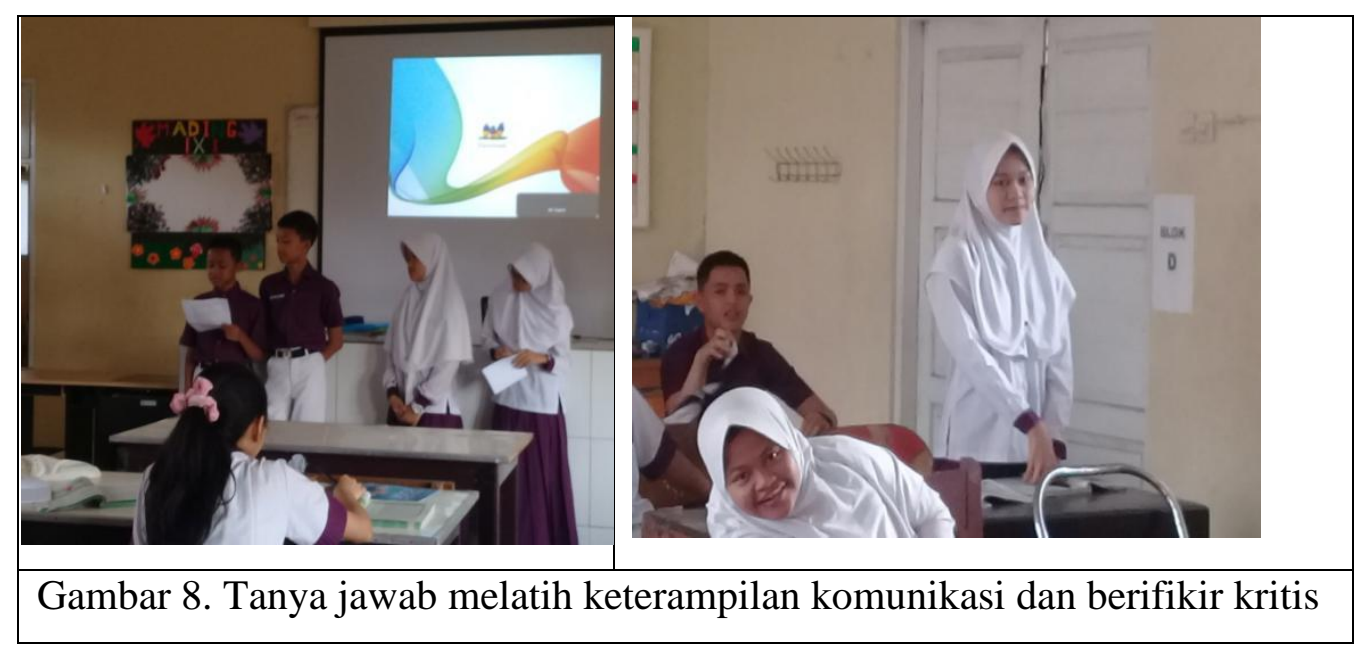

Pada gambar 8, beberapa kelompok mempresentasikan hasil kegiatan window Shopping dan hasil diskusi kelompok untuk menjawab pertanyaan pada LKPD sistem reproduksi manusia. Kegiatan presentasi dan Tanya jawab melatih keterampilan komuikasi dan berfikir kritis yang merupakan keahlian abad 21 yang harus dimiliki peserta didik.

Hasil belajar Peserta didik dalam pembelajaran Sistem Reproduksi Manusia dengan model Discovery Learning melalui Aktivitas Two Stay Two Stray (TSTS) dan Window Shopping ditunjukkan pada tabel 1.

Tabel 1 Hasil Belajar Peserta Didik

\begin{tabular}{lll}
\hline & Pra Tindakan & Tindakan \\
\hline RATA_RATA & 70,0 & 84,0 \\
$<76$ & 24 & 1 \\
$>76$ & 7 & 30 \\
TB & 21,9 & 93,8 \\
DS & 25,7 & 100,0 \\
\hline
\end{tabular}

Data tersebut disimulasilam dalam bentuk grafik sebagai berikut: 


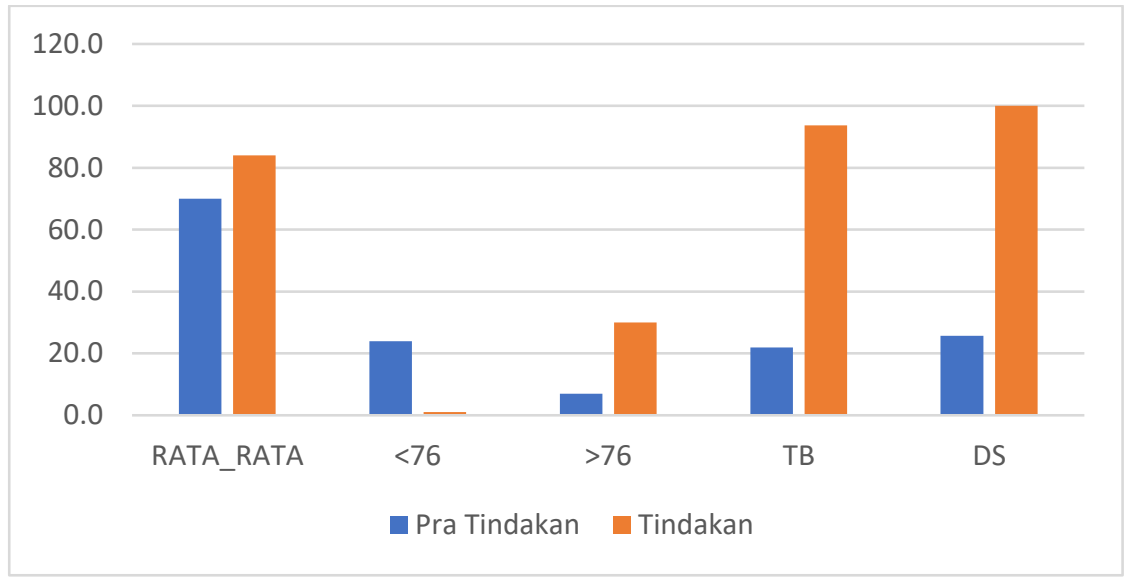

Grafik doiatas menunjukkan kegiatan pembelajaran discovery learning melalui aktivitas TSTS dan window Shopping berpengaruh positif terhadap hasil belajar peserta didik. Rata-rata nilai pengetahuan peserta didik setelah melakukan model pembelajaran tersebut sebesar 84 lebih tinggi dibandingkan KKM IPA kelas IX yang ditetapkan SMP N 1 Cilacap. Daya serap peserta didik mencapai $100 \%$ dan ketuntasan belajar mencapai $93.8 \%$. walaupun ada satu peserta mendapat nilai diawah KKM karena kesibukan tidak mengikuti setiap kegiatan pembelajaran discovery learning melalui aktivitas TSTS dan window Shopping.

\section{SIMPULAN}

Berdasarkan pembahasan dan pemecahan masalah sebagaimana yang telah diuraikan di atas, maka dapat disimpulkan sebagai berikut: hasil belajar peserta didik kelas IX J SMP Negeri 1 Cilacap Tahun Pelajaran 2019/2020 setelah mengikuti pembelajaran Sistem Reproduksi Manusia model Discovery learning melalui aktivitas Two Stay Two Stray (TSTS) dan window Shopping diperoleh rata-rata nilai pengetahuan sebesar 84 lebih tinggi dibandingkan KKM IPA kelas IX yang ditetapkan SMP N 1 Cilacap. Daya serap peserta didik mencapai 100\% dan ketuntasan belajar mencapai $93.8 \%$

\section{DAFTAR PUSTAKA}

Suprijono. Agus (2009).Cooperatif Learning Teori dan Aplikasi PAIKEM. Yogyakarta:PT.Pustaka Pelajar. 
Greenstein, L., 2012, Assessing 21 Century Skills: A Guide to Evaluating Mastery and Authentic Learning. California: Corwin.

Leen, C.C., Hong, K.F.F.H., dan Ying, T.W., 2014, Creative and Critical Thinking in Singapore Schools. Singapore: Nanyang Technological University.

Papp, KK., Huang, G.C., Clabo, L.L.M.,Delva, D., Fischer, M., Konopasek,I., Schwartzsein, R.M., dan Gusic,M., 2014, Milestones of Critical Thinking: A Developmental Model for Medicine and Nursing.Academic Medicine, Vol 89, No 5, Hal 715-720.

Rahma, W. 2017. Pengaruh penggunaan metode kooperatif window shopping terhadap partisSistem Reproduksi Manusiasi bimbingan konseling klasikal. Jurnal Penelitian Pendidikan Indonesia (JPPI) Vol. 2, No. 2, April.

Putra. Sitiatava Rizema 2013 , Desain Belajar Mengajar Kreatif Berbasis Sains .Yogyakarta : Diva Press

Syah. 2004. Psikologi Pendidikan dengan Pendekatan Baru. Bandung: PT Remaja Rosdakarya.

Sa'diyah. Aniatus.2016. Prilakuku Pemanfaatan Perpustakaan Kafee (Library Cafee) Sebagai gaya hidup (Life Style) Masyaraktat Kota Surabya. Universitas Airlangga. Surabaya

Zubaidah .Siti dkk. 2017. Buku Guru Ilmu Pengetahuan Alam kelas

VIII.Jakarta:Kementerian Pendidikan dan Kebudayaan

Yusritawati. 2009. Pengaruh Penerapan Model Pembelajaran Kooperatif Teknik Two Stay Two Stray terhadap Kemampuan Representasi Matematika Peserta didik SMP. Bandung : Jurusan Pendidikan Matematika FKIP UNPAS 